\title{
Reproductive performance improvement in Iraqi buffaloes by using different hormonal regimes
}

\author{
J .R. AL-Shmmary T. M. Al-Hamedawi \\ Coll. of Vet. Med. -Univ. of Baghdad
}

\begin{abstract}
The present study was performed on 153 Iraqi cow buffaloes, suffered from ovarian inactivity after 60 days from calving, in Babylon province in period from November 2012 to August 2013. The affected animals were divided into four groups randomly according to the hormonal treatment regime, 48 cow buffalo treated with 1000 I.U/I.M of PMSG in one does in day 60 postpartum, which represents the $1^{\text {st }}$ group, while the $2^{\text {nd }}$ group include 45 cow buffalo treated with $0.021 \mathrm{mg} / \mathrm{I}$.M of GnRH (Receptal) in one does in day 60 postpartum, but the 3 rd group ( 36 cow buffaloes) treated with hCG 1500 I.U/I.M in a single dose also after 60 days postpartum, while $4^{\text {th }}$ group (24 cow buffalo) was represented the control group(without treatment). The response animals for different hormonal treatment were $87.2 \%, 80 \%, 69.4 \%$ and $54.1 \%$ for the $1^{\text {st }}, 2^{\text {nd }}, 3^{\text {rd }}$ and $4^{\text {th }}$ group respectively. The $1^{\text {st }}$ group which treated with PMSG give higher significant differences $(\mathrm{p}<0.01)$ compared with other groups, also the $2^{\text {nd }}$ group (treated with GnRH) record significant differences $(\mathrm{p}<0.01)$ compared with $3^{\text {rd }}$ and $4^{\text {th }}$ group. The duration of response also record higher significant differences $(p<0.01)$ between $1^{\text {st }}$ and $2^{\text {nd }}$ group compared with $3^{\text {rd }}$ and $4^{\text {th }}$ group, while the number of services per conception was no different between all groups, but the pregnancy rate record superior significant differences $(\mathrm{p}<0.01)$ for the $1^{\text {st }}$ group compared with other groups and reached to $85 \%$ but the $4^{\text {th }}$ group (control group) record low ratio compared with treated groups. Finally the days open was recorded superior significant differences between $1^{\text {st }}$ and $2^{\text {nd }}$ group compared with $3^{\text {rd }}$ and $4^{\text {th }}$ group, also $4^{\text {th }}$ group record long postpartum period $(175.82 \pm 13.56$ days). They concluded in this study that the hormonal treatment still an important method to treated the ovarian inactivity and this fact depends on the many reproductive parameters which involve the rate of response animals, duration of response, number of services per conception, pregnancy rate and days open.
\end{abstract}

Key words: Buffalo, PMSG, GnRH, hCG , ovarian inactivity.

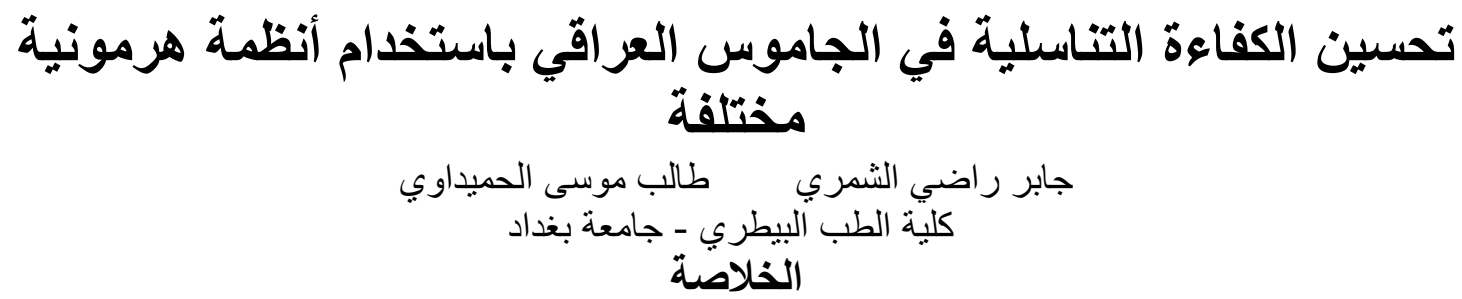

تم إجر اء هذه الدر اسة على 153 جاموسة عر اقية تعاني من حالة خمول المبايض بعد 60 يوم من و لاداتها وذلك إنك

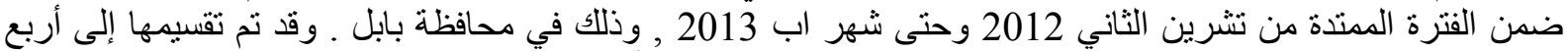

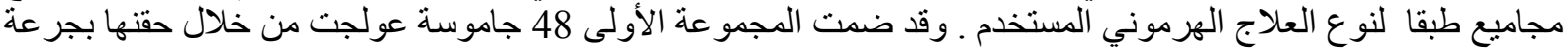

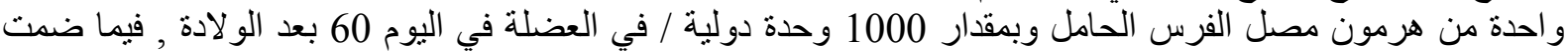

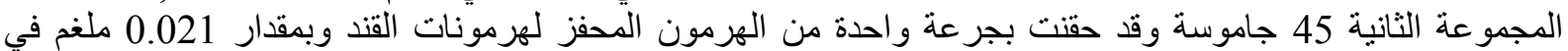

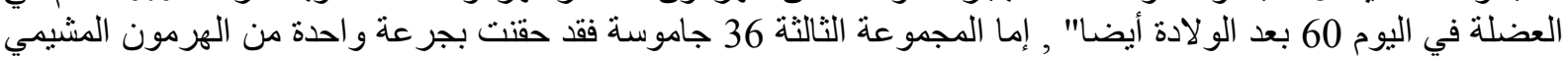

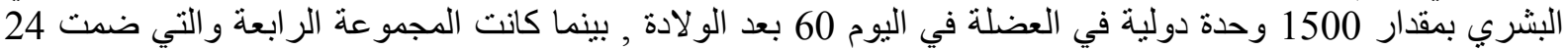

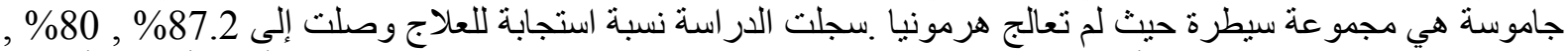

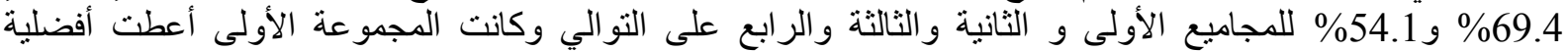

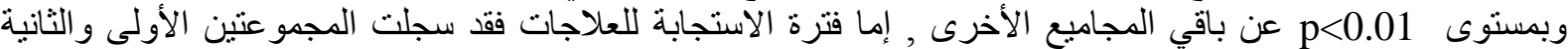

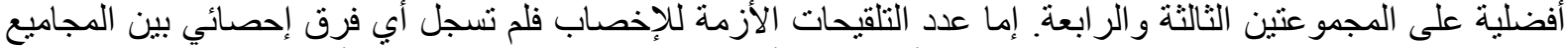

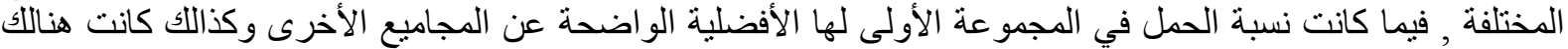

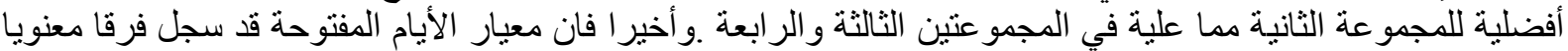

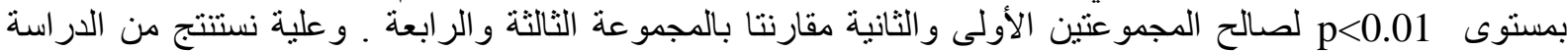
الحالية إن حالة خمول المبايض تحتاج إلى تداخل علاجي ( هرموني ) من خلال الحقيقة التي تعتمد على الكثير من المعاير 
التكاثرية و التي تشمل نسبة الاستجابة , فترة الاستجابة , نسبة الحمل , معدل الأيام المفتوحة و التي تحسنت كثبر ا باستخدام

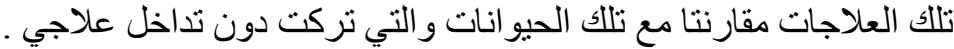

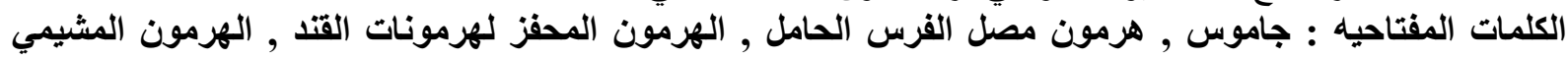
البشري , خمول المبايض .

\section{Introduction}

Buffaloes are polyestrous continuous species and show estrous all year around, however a seasonal pattern has been reported from different countries of the world (1),(2). Such characteristic related as a seasonal polyestrous is more related to ambient temperature, photoperiod and feed supply. In addition with the possibility of the use of hormonal control of estrus cycle, seasonal pattern can be overcome and they can bred through the synchronization of the estrous cycle in the year around (3). Reproductive problems such as delayed puberty, ovarian inactivity are the main obstacles for improving this species (4), (5), (6), (7). Many authors reported that the administration of hormones include PMSG, GnRH, Progesterone or hCG during early postpartum period has conception (8),(9). The effect of ovarian inactivity is including increase period of first estrus postpartum, number of services per conception, pregnancy rate and days open (7),(10),(11),(12), (13). The purposes of this study were to evaluate different hormonal regimes for treatment ovarian inactivity and the effects on reproductive parameters (response animal, services per conception , pregnancy rate, days open) to improvement the reproductive performance in Iraqi buffaloes.

\section{Materials and methods}

This study was performed on 153 cow buffaloes between 3-7 years old in Babylon province and these animals suffered from ovarian inactivity after 60 days postpartum during the period from 2012-2013. These animals were divided randomly into four groups, $1^{\text {st }}$ group include 48 buffaloes treated by single dose of PMSG* 1000 I.U/I.M/Animal in the day 60 postpartum, $2^{\text {nd }}$ group (45 buffaloes) treated with a single dose of $\mathrm{GnRH}^{* *} 0.021 \mathrm{mg} / \mathrm{I} . \mathrm{M} /$ Animal in the day 60 postpartum, $3^{\text {rd }}$ group (36 buffaloes) treated with 1500 I.U/I.M/ Animal from $\mathrm{hCG}^{* * *}$ in single dose in the day 60 postpartum also and $4^{\text {th }}$ group ( 24 buffaloes) without treatment and considered as a control group. Response of animals and duration of response as well as the number of services per conception, pregnancy rate and days open were recorded. Statistical analysis for data of this study includes Mean, Standard error, Chi-Square and F-test to (14). * IntervetInternatioal B .V. Boxmeer-Holland. ** Intervet-International B.V. Boxmeer Holland. *** Yougie - dong JK san- Si, Jonbuk- do, Korea.

\section{Results and discussion}

The result showed in table-1- that the response cow buffaloes in $1^{\text {st }}$ group which injected with 1000 I.U/I.M of PMSG recorded $87.2 \%$ with higher significant difference $(\mathrm{p}<0.01)$ compared with $2^{\text {nd }}, 3^{\text {rd }}$ and $4^{\text {th }}$ groups $(80 \%, 69.4 \%$ and $54.1 \%$ respectively), these findings agreement with (15), (16) , while the duration of response was recorded $7.34 \pm 2.16$ days, $7.34 \pm 2.25$ days , $9.72 \pm 3.01$ days and $76.56 \pm 10.92$ days in the $1 \mathrm{st}, 2^{\text {nd }}, 3^{\text {rd }}$ and $4^{\text {th }}$ groups respectively and the $1^{\text {st }}$ and $2^{\text {nd }}$ groups recorded significant differences higher $p<0.01$ compared with $3^{\text {rd }}$ and $4^{\text {th }}$ groups and these results were agreement with many authors recorded. 4-7 days (17),(18) also (19) recorded 65-80 days iv buffaloes without treatment after 60 days postpartum. the number of services per conception in different groups are presented in table-2-, however all treated groups and untreated group (control groups) recorded on significant differences between $(p<0.01)$ and the number was $1.81 \pm 0.12,1.62 \pm 0.24$, $1.68 \pm 0.22$ and $1.93 \pm 044$ in $1 \mathrm{st}, 2^{\text {nd }}, 3^{\text {rd }}$ and $4^{\text {th }}$ groups respectively, however the findings supported by (20) which recorded $1.36 \pm$ 0.08 in overall status ( control and treated groups of buffaloes ). While the pregnancy rate showed in table -2- record superior significant differences $(\mathrm{p}<0.01)$ for the $1^{\text {st }}$ group compared with other groups and this results agreement with. (21) which reported overall conception rate was batter in PMSG $(77.87 \%)$ group than GnRH ( 29-64 $\%)$.Finally the service period (days open) was recorded higher significant differences in 
$1^{\text {st }}$ and $2^{\text {nd }}$ groups compared with $3^{\text {rd }}$ and $4^{\text {th }}$ groups and these information supported by many authors (22),(13) it was concluded that they using hormonal treatment include PMSG, GnRH and hCG was very effective for treatment ovarian inactivity in Iraqi buffaloes and improvement reproductive performance compared with treated animal and success to induce days open and increased pregnancy rates.

Table-1-: Different methods of treatment, response and duration of response in Iraqi buffaloes.

\begin{tabular}{|c|c|c|c|c|c|}
\hline Group & $\begin{array}{l}\text { No. of } \\
\text { animals }\end{array}$ & Type of treatment & Anime & $\begin{array}{l}\text { response } \\
\%\end{array}$ & $\begin{array}{l}\text { Duration } \\
\mathrm{M} \pm \mathrm{SE}\end{array}$ \\
\hline G 1 & 48 & $\begin{array}{l}\text { (Folligon) } \\
\text { (PMSG) eCG } \\
\text { 1000 I.U/I.M }\end{array}$ & 41 & $87.2 \mathrm{a}$ & $\begin{array}{c}7.34 \pm 2.16 \\
\mathrm{a}\end{array}$ \\
\hline G2 & 45 & $\begin{array}{c}\text { GnRH(Receptal) } \\
0.021 \mathrm{MG} / \mathrm{I} \mathrm{M}\end{array}$ & 36 & $80 \mathrm{~b}$ & $\begin{array}{c}7.34 \pm 2.25 \\
\mathrm{a}\end{array}$ \\
\hline G3 & 36 & $\begin{array}{l}\text { HCG (I.V.F) } \\
1500 \text { I.U /I.M }\end{array}$ & 25 & $69.4 \mathrm{c}$ & $\begin{array}{c}9.72 \pm 3.01 \\
b\end{array}$ \\
\hline G4 & 24 & Without treatment & 13 & $54.1 \mathrm{~d}$ & $\begin{array}{c}76.56 \pm 10.92 \\
\text { c }\end{array}$ \\
\hline \multirow{2}{*}{ TOTAL } & \multirow{2}{*}{153} & & \multicolumn{2}{|c|}{$\begin{array}{c}\text { Treat animal } \\
\text { a } \\
79.06 \% \\
\end{array}$} & \\
\hline & & & \multicolumn{2}{|c|}{$\begin{array}{c}\text { Control } \\
13 / 24 \mathrm{~b} \\
54.1 \%\end{array}$} & \\
\hline
\end{tabular}

Different letters mean sig. differences $(\mathrm{P}<0.01)$

Table -2- Showed the NO. of services / conception and days open in Iraqi buffaloes .

\begin{tabular}{|c|c|c|c|c|c|}
\hline Group & $\begin{array}{c}\text { No. of } \\
\text { animals }\end{array}$ & $\begin{array}{c}\text { No .of services per } \\
\text { conception } \\
\mathrm{M} \pm \mathrm{SE}\end{array}$ & & $\begin{array}{l}\text { snancy } \\
\text { Rate }\end{array}$ & $\begin{array}{c}\text { Days open } \\
\mathrm{M} \pm \mathrm{SE}\end{array}$ \\
\hline G1 & 41 & $1.81 \pm 0.12 \mathrm{a}$ & 35 & $85.3 \mathrm{a}$ & $\begin{array}{c}98.21 \pm 6.35 \\
\mathrm{a}\end{array}$ \\
\hline $\mathrm{G} 2$ & 36 & $1.62 \pm 0.24 \mathrm{a}$ & 28 & $77.7 \mathrm{~b}$ & $\begin{array}{c}101.52 \pm 7.26 \\
\mathrm{a}\end{array}$ \\
\hline G3 & 25 & $1.68 \pm 0.22 \mathrm{a}$ & 16 & $64 c$ & $\begin{array}{c}107.34 \pm 6.42 \\
b\end{array}$ \\
\hline G4 & 13 & $1.93 \pm 0.44 \mathrm{a}$ & 8 & $61.5 \mathrm{c}$ & $\begin{array}{c}175.82 \pm 13.56 \\
\mathrm{c}\end{array}$ \\
\hline TOTAL & 115 & ---- & & & ----------- \\
\hline
\end{tabular}

Different letter mean sig. differences $(\mathrm{p}<0.01)$.

\section{References}

1-Gangwar, P.C.(1980). Climate and reproduction in buffaloes a review. India J. Dairy. Sci., Bangalore, 33 (4): 419-426.

2-Sane, C.R. ;Luktuke, S. N.; Deshpande, B. R.; Kaikini, A. S.; Velhenker, D. P,; Hukeri, V. B.; and Kodagali, B. S, (1982). A Textbook of Reproduction in Farm Animals (Theriogenology). Varghese Puplishing House, Hind Rajsthan
Building, Dadasaheb Phalke Road, Bomby400014.

3-Vale,W.G.and Chantalakhana,C.(2005). Livestock and wealth creation-improving the husbandry of animals kept by poor people in developing countries.Chapter 22. Buffalo. Livestock production programme. Natural resources. International Ltd. U.K.p 601. 
4-Sharma, R. K. (2003). Reproductive problems of buffaloes and their management compendium of lectures delivered to the cent. Inst. Res. Buffaloes, Hisar, India 119-126.

5-Hassan H.(2005). Delayed age of puberty in buffalo heifer. Proc. The $12^{\text {th }}$ intern. Soc. Anim. Hygiene, Warsaw, Poland: 159-162.

6-Ahmed, M.W. (2006). Adverse condition affecting ovarian activity in large farm animals- Proceeding of the $3^{\text {rd }}$ Inter. Conf. of Vet. Research Division. Nat. Res. Cent. Cairo, Egypt. 251-253.

7-Ahmed, W.M.;Zaabal, M.M. and Abd.EI-Hameed, A.R.(2010).Relationship between ovarian activity and blood lead concentration in cows and buffaloes with emphases on gene frequencies of hemoglobin. Global. $\mathbf{J}$. of Biotech and Biochem.5(1):01-05.

8-Baruselli, P.S.; Vaina,R.G. and Mucciolo, C.A.(1994). Oliveira and Madureira,E.H.(1994). Overian activity and reproductive behavior during the postpartum in buffaloes. Proc. $4^{\text {th }}$ World Buff. Cong. Sao Paulo. Brail 27-30 june Vol. 3, 641-647

9-Gogoi,P.K.; Das, D and Goswami,R.N.(1969). Performance of swamp buffaloes of assam in respect of some important reproductive trails. J. of the assam Vet. 6: 19-21.

10- Roberts, S.Y., and Walter, R.T., (2007). Current therapy in large animal theriogenology $2^{\text {nd }} \mathrm{Ed}$. Saunders - Elssevier.

11-El-Malky, (2007). Factors affecting on retained placenta in buffaloes. PhD thesis, Fac. of Agric. Menufeia Univer., Egypt.

12-Yindee,M.;Techakumphu, M.; Lohachit, C.; Sirivaidyapong, S.; Nachiangmai, A.; RodriguezMartinez, H.; van der Weyden, G.C. and Colenbrander, B.(2010). Follicular dynamics and oestrous detection in thai postpartum swamp buffaloes(Bubalus bubalis).
13-Perera.B.M.A.O.(2011). Reproductive cycles of buffalo. Anim. Reprod. Sci. 124: 194-199.

14- Steel, R.G.D. and Torrie, H.J. (1981). Principles and procedures of statistics. $2^{\text {nd }}$ Ed. McGraw Hill, London.

15-Situmorang, P.(2003). Superovulation in different buffalo genotypes.J.I.T.V. 8(1): 40-45.

16-De Rensis F.; Ronci, G.; Guarneri P.; Nguyen BX.; Presicce, and Huszenicza GA.(2005). Conception rate after fixed time insemination following Ovsynch protocol with and without progesterone supplementation in cyclic and noncyclic Mediterranean Italian buffaloes(Bubalus bubalis). Theriogenology, 63: !824-1831.

17-Pineda, M.H.(2003). McDonalds Veterinary Endocrinology and Reproduction. $5^{\text {th }}$ ed. Ames: Iowa State University Press. Pp. 17-34.

18-Herbert, C.A.; Trigg, T.E.(2005). Applications of $\mathrm{GnRH}$ in the control and management of fertility in female animals. Anim. Reprod. Sci, 88: 141153.

19-Zaabel, S.M.; Hegab,A.O.; Montasser, A.E. and EI-Sheikh, H.(2009). Reproductive performance of anestrous buffaloes treated with CIDR. Anim. Reprod.,6,(3):460-464.

20- Khasatiya, C.T.; Kavani,F.S.; Dhami, A.J.; Derashri, H.J.; Panchal, M.T. and Desai, P.M.(2006). Studies on puerperal events and reproductive efficiency following hormone therapy at day 42 postpartum in surti buffaloes.

21- Prahalad, P.; Sadasiva Rao, K. and Solmon Raju, K.G.(2010). Effect of GnRH, PMSG and placentrex on reproductive performance of postpartum true anestrus.

22-Channa, A. A.; Kunbhar, H. K.; Samo, M.U.; Mirbahar, K.B. and Kaka, I . (2006). Treatment of retention of placenta and its effect on subsequent fertility rate in buffaloes pak. J. Agri., Agril. Engg., Vet. Sci. 22(1). 